\title{
Comparison of Total Self-Stigma Between Schizophrenia and Alcohol Dependence Patients
}

\author{
Lipsy Modi ${ }^{1}$, Sachin Ratan Gedam ${ }^{1,}{ }^{*}$, Imran Ali Shivji $^{1}$, Vijay Babar $^{2}$ and P S Patil ${ }^{1}$ \\ ${ }^{1}$ Department of Psychiatry, Jawaharlal Nehru Medical College, Sawangi (Meghe), Wardha, Maharashtra, India \\ ${ }^{2}$ Department of Community Medicine, Jawaharlal Nehru Medical College, Sawangi (Meghe), Wardha, Maharashtra, India \\ "Corresponding author: Sachin Ratan Gedam, Department of Psychiatry, Jawaharlal Nehru Medical College, Sawangi (Meghe), Wardha, Maharashtra, India. Tel: +91-7152287701, \\ E-mail: sachinrgedam@gmail.com
}

Received 2017 September 20; Accepted 2018 February 21.

\begin{abstract}
Background: Self-stigma severely affects individuals suffering from psychiatric disorders such as schizophrenia and alcohol dependence syndrome (ADS) as well as act as a barrier to recovery process.

Objectives: This study attempted to measure and compare self stigma among schizophrenia and alcohol dependence syndrome patients.

Patients and Methods: A cross-sectional study performed on 100 patients, 50 patients with ADS and 50 patients with schizophrenia. A semi-structured data and internalized stigma of mental illness Scale (ISMIS) to assess self-stigma were administered.

Results: Prevalence of self-stigma was more in ADS (66\%) than that in schizophrenia (50\%). The stigma in schizophrenia was significantly associated with unmarried and divorced; education above 12th standard; those who belonged to joint family, and urban region $(P<0.05)$ while in ADS, it was associated with education above 12th standard $(\mathrm{P}<0.05)$. Only gender among the sociodemographic correlates was significantly different between schizophrenia and ADS patients with self stigma $(\mathrm{P}<0.05)$. The locality and education status were found to be strong predictors of stigma.

Conclusions: Self stigma is more prevalent in ADS as compared to schizophrenia and it is a significant problem in both. Therefore, there is a need to take specific interventions to improve overall quality of life and reduce stigma.
\end{abstract}

Keywords: Stigma, Schizophrenia, Alcohol Dependence, Mentally Ill, Risk Factors

\section{Background}

Stigma is defined as "an attribute that is deeply discrediting," where a person is lowered "from a whole and usual person to a tainted, discounted one" (1). It is divided into public stigma and self-stigma. Public stigma is the reaction of the general population towards people with mental illness. Self stigma is the prejudice, in which people turn against themselves. Stereotypes, prejudice, and discrimination are the three components of both self and public stigma (2). Patients experiencing stigma suffer consequences such as increased social isolation, decreased treatment access, and limited life chances. The sources of stigma include community, co-workers, family, mental health caregivers, religious places, etc. $(3,4)$. Internalized stigma or self stigma has also been related with negative outcomes such as depression, social avoidance and avoidance coping, decreased hope and self-esteem, decreased access to mental health services and other supports, as well as worsening of psychiatric symptoms (5-8).
A number of previous studies reported rise of selfstigma in psychiatric disorders in recent years $(9,10)$. These studies were conducted homogenously on schizophrenia and spectrum disorders while others focused on nonhomogenous mental disorder groups such as schizophrenia, mood, personality, and anxiety disorder subjects (11, 12). As compared to other psychiatric disorders, the patients with schizophrenia experience more stigma $(13,14)$. A recent study reported the prevalence of internalized stigma to be $29.4 \%$ among schizophrenia patients (15). The literature reported that inter-individual and intraindividual variables might decrease or increase the stigma impact on health-related outcomes (16). It has been found that socio-demographic factors are marginally related to personal stigma and on the other hand psychosocial variables such as quality of life inversely related to personal stigma. The variables such as age of onset, lifetime number of hospitalization, and duration of illness reported significant associations with personal stigma $(17,18)$.

In contrast to schizophrenia patients, literature inves- 
tigating self-stigma in alcoholism is limited. Alcohol dependence is one of the most common mental disorders (19). Alcoholism has a negative impact on social behavior, social environment, and social interactions (20). The stigma related to alcoholism may hinder the seeking of professional help; increasing these effects and experiencing discrimination and loss of status. Therefore, it may lead to social exclusion, particularly in those who need social support (21). As compared to other psychiatric illnesses, people with ADS face strong rejection and negative stereotypes like being unpredictable or being danger $(22,23)$. Stigma ascribed to patients with substance use contributes to non-completion of treatment, poor mental and physical health, poor reintegration and recovery processes, and increased involvement in risky behavior (24, 25).

This study was done due to the fact that a number of attempts have been made to measure attitude toward psychiatric illness and stigma, particularly held by people in the community, a family member, and a caregiver rather than the patients themselves $(26,27)$; comparative studies among persons with different mental disorders show that their attitudes are illness specific $(23,28)$; and we might expect differences in the demographic variables of stigma related to other mental disorders compared with demographic variables of alcohol disorder stigma (29). In our set up, we get patients mostly suffering from schizophrenia and ADS, with higher dropout rates and poor compliance. Therefore, we choose these two groups of patients in this study. To the best of our knowledge, there are no studies comparing stigma in schizophrenia and alcohol dependence syndrome (ADS). Developing an understanding into the stigma of these disorders will be important to help these individuals, their family members, caregivers, and treatment providers. Thus, in this study we tried to find out how stigma of schizophrenia compare with stigma of alcohol dependence syndrome.

\section{Objectives}

The present study aimed to comparison of total self stigma between schizophrenia and alcohol dependence patients.

\section{Patients and Methods}

A cross sectional study was performed on patients attending the Psychiatry unit of Acharya Vinoba Bhave Rural hospital, Wardha, Maharashtra during the period of AprilJune 2016. The study was conducted on obtaining the institutional ethics committee approval and patient's written informed consent after providing necessary information. A total of 100 patients, aged 18 to 60 years, who were able to read and understand Hindi, were selected through purposive sampling as per the inclusion and exclusion criteria of the present study. Of the total patients, 50 were diagnosed as schizophrenia and 50 as alcohol dependence syndrome for comparison according to international classification of diagnostic criteria (ICD-10). The patients having co-morbid medical or other psychiatric illness, un co-cooperative, organic brain syndrome, mental retardation, and in need of emergency medical care were excluded from the study.

\subsection{Tools}

1- Semi-structured data was used to collect the sociodemographic and clinical details such as age, gender, education, marital status and employment, type of family, locality, duration, and current status of illness.

2- Internalized stigma of mental illness scale (ISMIS): It is used to assess self stigma/internalized stigma, from the perspective of stigmatized individuals. It comprises of 29 questions divided into five components (alienation, perceived discrimination, stereotype endorsement, social withdrawal, and stigma resistance). All items were assessed on a 4-point Likert-type scale ( 1 = strongly disagree to $4=$ strongly agree). The higher score shows the higher, level of stigma. The originator of the scale used a cut off value of 2.5 for ISMIS to categorize the presence or absence of stigma. The Hindi version of ISMIS used in this study is validated. The Cronbach's alpha was found to be 0.863 for estimation of internal consistency of the Hindi version scale. Accordingly, it can be concluded that the Hindi version of ISMI Scale has a good internal consistency and that the items of the scale assess similar characteristics $(30,31)$.

\subsection{Statistical Analysis}

The SPSS version 17.0, graph pad prism 6.0 and EPI INFO 6.0 version were used for statistical analysis of the data collected. Descriptive and inferential statistics, chi-square test, and multiple regression models were used for analysis. P value was calculated considering significant level at 0.05 .

\section{Results}

\subsection{Socio-Demographic and Clinical Data}

A total of 100 patients were selected in the study, out of which half were diagnosed as schizophrenia and half as alcohol dependence syndrome (ADS). Table 1 reported the socio-demographic and clinical data of both groups. The majority of the patients were 30 - 45 years of age (52\% for schizophrenia and 66\% for ADS) and married (56\% for both 
the groups) followed by unmarried and divorced. There were $48 \%$ of males and $52 \%$ of females among schizophrenia patients, whereas no females among ADS patients. Most of the patients were educated up to 5 th standard (32\% for schizophrenia and 36\% for ADS), employed (58\% for schizophrenia and 54\% for ADS), and belonged to a nuclear family (74\% for schizophrenia and 66\% for ADS). Most of them belonged to rural locality (52\% for schizophrenia and $68 \%$ for ADS). Most of the patients had a duration of illness between 1 to 5 years ( $40 \%$ for schizophrenia and $44 \%$ for ADS) and were not under remission (78\% for schizophrenia and $68 \%$ for ADS).

\subsection{Correlation with Socio-Demographic and Clinical Parame- ters}

As shown in Table 2, stigma scores of schizophrenia patients were significantly different for unmarried and divorced, those who were educated above 12th standard, and belonged to a joint family and urban region $(\mathrm{P}<0.05)$. The stigma scores were not significantly affected by the other variables. As shown in Table 3, stigma scores of ADS patients were significantly different for those educated above 12th standard $(\mathrm{P}<0.05)$ whereas none of the other variables reported significant differences $(\mathrm{P}>0.05)$.

\subsection{Correlation of Parameters Between Schizophrenia and ADS Patients with Positive Total Stigma Scores}

As shown in Table 4, the gender had a significant difference between schizophrenia and ADS patients with positive total stigma scores $(\mathrm{P}<0.05)$. Whereas; age, marital status, educational status, employment status, family type, locality, current status of illness, and duration of illness had no significant difference $(\mathrm{P}>0.05)$.

\subsection{Prevalence of Stigma Scores}

Prevalence of total stigma scores was 50\% and 66\% for schizophrenia and ADS patients, respectively. Stereotype endorsement, stigma resistance, and total stigma scores reported a significant difference between both groups of patients $(\mathrm{P}<0.05)$ (Table 5).

\subsection{Predictors of Stigma Scores}

Multiple regression analysis was done considering a total stigma score as dependent variable, whereas clinical and socio-demographic characteristics were independent variables. The locality of the patient was a predictor of stigma score for schizophrenia patients. Whereas it has been found that education status and locality were predictors of stigma score for ADS patients (Tables 6 and 7).

\begin{tabular}{|c|c|c|}
\hline Variables & Schizophrenia & ADS \\
\hline \multicolumn{3}{|l|}{ Age, years } \\
\hline Less than 30 & $16(32)$ & $7(14)$ \\
\hline $30-45$ & $26(52)$ & $33(66)$ \\
\hline More than 45 & $8(16)$ & $10(20)$ \\
\hline \multicolumn{3}{|l|}{ Sex } \\
\hline Male & $24(48)$ & $50(100)$ \\
\hline Female & $26(52)$ & $0(0)$ \\
\hline \multicolumn{3}{|l|}{ Marital status } \\
\hline Married & $28(56)$ & $28(56)$ \\
\hline Unmarried & $12(24)$ & $15(30)$ \\
\hline Divorced & $10(20)$ & $7(14)$ \\
\hline Widow & $0(0)$ & $0(0)$ \\
\hline Others & $0(0)$ & $0(0)$ \\
\hline \multicolumn{3}{|l|}{ Education status } \\
\hline $1^{\text {st }}-5^{\text {th }}$ std & $21(42)$ & $19(38)$ \\
\hline $6^{\text {th }}-10^{\text {th }}$ std & $19(38)$ & $15(30)$ \\
\hline $11^{\text {th }}-12^{\text {th }}$ std & $6(12)$ & $8(16)$ \\
\hline Above $12^{\text {th }}$ std & $4(8$ & $8(16)$ \\
\hline \multicolumn{3}{|l|}{ Employment status } \\
\hline Not working currently & $21(42)$ & $23(46)$ \\
\hline Working currently & $29(58)$ & $27(54)$ \\
\hline \multicolumn{3}{|l|}{ Family type } \\
\hline Nuclear & $37(74)$ & $33(66)$ \\
\hline Joint & $13(26)$ & $17(34)$ \\
\hline \multicolumn{3}{|l|}{ Locality } \\
\hline Rural & $26(52)$ & $34(68)$ \\
\hline Urban & $24(48)$ & $16(32)$ \\
\hline \multicolumn{3}{|l|}{ Duration of illness, years } \\
\hline $1-5$ & $20(40)$ & $22(44)$ \\
\hline $6-10$ & $15(30)$ & $17(34)$ \\
\hline More than 10 & $15(30)$ & $11(22)$ \\
\hline \multicolumn{3}{|l|}{ Current status of illness } \\
\hline Under remission & $11(22)$ & $16(32)$ \\
\hline Not under remission & $39(78)$ & $34(68)$ \\
\hline
\end{tabular}

\section{Discussion}

This study attempted to measure and compare self stigma among schizophrenia and alcohol dependence syndrome patients. Researches related to perceived self stigma in psychiatric disorders generally conducted were 


\begin{tabular}{|c|c|c|c|c|}
\hline Variables & $\begin{array}{l}\text { Schizophrenia Patients with Self-Stigma } \\
\qquad\left(T^{\mathbf{a}}\right)\end{array}$ & $\begin{array}{l}\text { Alcohol Dependent Patients with } \\
\text { Self-Stigma }\left(T^{\mathbf{a}}\right)\end{array}$ & Chi Square Test & PValue $^{\text {b }}$ \\
\hline Age, $y$ & & & 2.39 & $0.30, \mathrm{NS}$ \\
\hline Less than 30 & 9 & 6 & & \\
\hline $30-45$ & 12 & 21 & & \\
\hline More than 45 & 4 & 6 & & \\
\hline Sex & & & 17.92 & $0.0001, S$ \\
\hline Male $(n=24)$ & 14 & 33 & & \\
\hline Female $(n=26)$ & 11 & 0 & & \\
\hline Marital status & & & 2.05 & 0.35 , NS \\
\hline Unmarried & 5 & 11 & & \\
\hline Divorced & 7 & 5 & & \\
\hline Widow & 0 & 0 & & \\
\hline Others & 0 & 0 & & \\
\hline Education status & & & 3.43 & $0.48, \mathrm{NS}$ \\
\hline $1^{\mathrm{st}}-5^{\mathrm{th}}$ std & 12 & 15 & & \\
\hline $6^{\text {th }}-10^{\text {th }}$ std & 7 & 8 & & \\
\hline $11^{\text {th }}-12^{\text {th }}$ std & 3 & 5 & & \\
\hline Above $12^{\text {th }}$ std & 2 & 1 & & \\
\hline Employment status & & & 0.11 & $0.73, \mathrm{NS}$ \\
\hline Family type & & & 0.45 & $0.50, \mathrm{NS}$ \\
\hline Nuclear & 18 & 21 & & \\
\hline Joint & 7 & 12 & & \\
\hline Locality & & & 0.02 & 0.88 , NS \\
\hline Rural & 23 & 30 & & \\
\hline Urban & 2 & 3 & & \\
\hline Duration of illness, years & & & 2.33 & $0.31, \mathrm{NS}$ \\
\hline $1-5$ & 10 & 17 & & \\
\hline $6-10$ & 7 & 11 & & \\
\hline More than 10 & 8 & 5 & & \\
\hline Current status of illness & & & 0.47 & $0.48, \mathrm{NS}$ \\
\hline Under remission & 9 & 14 & & \\
\hline Not under remission & 16 & 17 & & \\
\hline
\end{tabular}

${ }^{\mathrm{a}} \mathrm{T}$, Total self-stigma scores.

${ }^{\mathrm{b}} \mathrm{NS}$, non significant and S, significant with P value $<0.05$.

neither on a homogenous group of illness nor comparative studies. To the best of our knowledge, it is the kind of first study conducted.

A review of literature reported internalized stigma in schizophrenia patients to be $29.4 \%$ and $41.7 \%$, respectively $(15,32)$. Literature of the comparative studies on stigma of alcoholism and other psychiatric disorder show that people suffering from alcohol dependence are severely stigma- 


\begin{tabular}{|c|c|c|c|c|c|c|c|}
\hline \multirow[t]{2}{*}{ Stigma Factors } & & \multicolumn{2}{|c|}{ Schozophrenia Patients } & \multicolumn{2}{|c|}{ ADS Patients } & \multirow[t]{2}{*}{$\chi^{2}$ Value } & \multirow[t]{2}{*}{ PValue $^{\text {b }}$} \\
\hline & & Absent & Present & Absent & Present & & \\
\hline Alienation & & $25(50)$ & $25(50)$ & $19(38)$ & $31(62)$ & 2.92 & $0.08, \mathrm{NS}$ \\
\hline Stereotype endorsement & & $26(52)$ & $24(48)$ & $17(34)$ & $33(66)$ & 6.61 & $0.010, S$ \\
\hline Discrimination experience & & $24(48)$ & $26(52)$ & $19(38)$ & $31(62)$ & 2.04 & 0.15, NS \\
\hline Social withdrawal & & $26(52)$ & $24(48)$ & $20(40)$ & $30(60)$ & 2.89 & $0.08, \mathrm{NS}$ \\
\hline Stigma resistance scores & & $23(46)$ & $27(54)$ & $31(62)$ & $19(38)$ & 5.15 & $0.023, \mathrm{~S}$ \\
\hline Total & & $25(50)$ & $25(50)$ & $17(34)$ & $33(66)$ & 5.25 & $0.021, \mathrm{~S}$ \\
\hline \multicolumn{8}{|c|}{$\begin{array}{l}{ }^{\mathrm{a}} \text { Values are expressed as No. (\%). } \\
{ }^{\mathrm{b}} \mathrm{NS} \text {, non significant and S, significant with P value }<0.05 .\end{array}$} \\
\hline \multirow[t]{2}{*}{ Parameters } & \multicolumn{2}{|c|}{ Unstandardized Coefficients } & & \multirow{2}{*}{\multicolumn{2}{|c|}{$\begin{array}{l}\text { Standardized Coefficients } \\
\text { Beta }\end{array}$}} & \multirow[t]{2}{*}{$\mathbf{t}$} & \multirow[t]{2}{*}{ PValue } \\
\hline & B & Std. Error & & & & & \\
\hline Stigma score & 2.248 & 0.390 & & & & & \\
\hline Age & 0.038 & 0.084 & & & & 0.456 & $0.651, \mathrm{NS}$ \\
\hline Gender & 0.113 & 0.095 & & & & 1.189 & $0.241, \mathrm{NS}$ \\
\hline Marital Status & 0.016 & 0.058 & & & & 0.266 & 0.791, NS \\
\hline Education & -0.009 & 0.041 & & & & 0.217 & $0.830, \mathrm{NS}$ \\
\hline Employment status & 0.101 & 0.098 & & & & 1.031 & 0.309, NS \\
\hline Family type & 0.101 & 0.108 & & & & 0.937 & 0.355 , NS \\
\hline Locality & -0.827 & 0.101 & & & & 8.201 & $0.0001, S$ \\
\hline Duration of illness & 0.065 & 0.065 & & & & 0.996 & 0.325 , NS \\
\hline Current status & -0.136 & 0.121 & & & & 1.126 & 0.267 , NS \\
\hline \multirow[t]{2}{*}{ Parameters } & \multicolumn{2}{|c|}{ Unstandardized Coefficients } & & \multirow{2}{*}{\multicolumn{2}{|c|}{$\begin{array}{l}\text { Standardized Coefficients } \\
\text { Beta }\end{array}$}} & \multirow[t]{2}{*}{$\mathbf{t}$} & \multirow[t]{2}{*}{ PValue } \\
\hline & B & Std. Error & & & & & \\
\hline Stigma score & 3.481 & 0.421 & & & & & \\
\hline Age & -0.095 & 0.093 & & & & 1.022 & 0.313, NS \\
\hline Marital status & -0.030 & 0.072 & & & & 0.409 & 0.685 , NS \\
\hline Education & -0.109 & 0.049 & & & & 2.254 & $0.030, \mathrm{~S}$ \\
\hline Employment status & -0.046 & 0.108 & & & & 0.426 & 0.672 , NS \\
\hline Family type & -0.035 & 0.116 & & & & 0.299 & 0.767, NS \\
\hline Locality & -0.476 & 0.131 & & & & 3.625 & $0.001, S$ \\
\hline Duration of illness & -0.088 & 0.071 & & & & 1.250 & 0.218, NS \\
\hline Current status & -0.160 & 0.137 & & & & 1.168 & $0.250, \mathrm{NS}$ \\
\hline
\end{tabular}

tized (33-35). Rohit et al., in his study also reported that substance dependence patients had higher stigma scores than schizophrenia patients (36). The present study determined internalized stigma in 50\% of schizophrenia patients and $66 \%$ of ADS patients. The stereotype endorse- ment (0.01), stigma resistance(0.023), and total ISMI scores (0.21) were found to be statistically significant between the two groups. Compared with the above studies, a high prevalence of self stigma was found in our study, which could be due to the heterogeneity of the sample and dif- 
ferences in severity of illness (37). Our study also reported that the prevalence of stigma in ADS was higher than schizophrenia. This may be due to the fact that they provoke more social rejection and more negative emotions, they are held much more responsible for their condition, less frequently considered as mentally ill, and at risk of structural discrimination (35).

The present study reported significant association of self stigma with marital status, education, type of family, and locality among schizophrenia patients whereas self stigma scores were not significantly affected by other socio-demographic variables. Different studies across the world correlating stigma with socio-demographic variables have found contrasting results. In these studies, self stigma was significantly associated with age and male gender (17) whereas some suggest lack of association with being married, living alone, and education (38-40). In addition, in a study by Rohit Garg et al., significantly higher stigma scores were reported in younger patients than older patients. This may be due to the fact that there are more understanding about their friends and more social interactions focusing on self attributes at a younger age (36). Previous studies also reported more stigma in patients with lower education than those with higher education $(41,42)$. It may be due to lower socioeconomic status and poverty in individuals with lower education. They are dependent on others for their employment and placed at the bottom in social hierarchy. This may contribute to a greater degree of social rejection, isolation, and internalization of feelings of stigma (36).

A study by Jadhav et al., showed higher stigma scores in rural samples than the urban sample. The reason may be that rural subjects showing supportive tolerant attitude as indicated by not covering up the illness, favorable response to living next door, and expecting the full return to normality (43). The rural individuals experienced more shame, ridicule, and discrimination whereas urban individuals felt the need to avoid and hide their illness in their job application (44). The reason for no significant association found in our study with respect to other variables may be due to socio-cultural and methodological differences.

The present study reported lack of association with clinical characteristics such as current status and illness duration among schizophrenia patients. Previous studies observed higher stigma scores in patients with longer illness duration and those who were not in remission (36). A review by Gerlinger et al., reported that age of onset, lifetime number of hospitalizations, and duration of illness had contradictory associations with self stigma (17). All these factors would be expected to increase the number of symptoms and severity of illness as well as expected to increase the actual stigmatizing responses of others and the person's stigma (36). The differences found in our study and previous studies in relation to clinical characteristics could be attributed to different questionnaires used to assess the stigma and differences in the psychosocial factors $(45,46)$.

Our study demonstrated that self stigma was significantly related to educational status of ADS patients, whereas none of the other socio-demographic variables had a significant difference. Previous studies suggested that stigma was significantly higher for men, individuals with lower income, lesser education, and individuals previously married as compared to those who had never been married (47). Consistent with these findings, the literature also suggested that women and persons with higher education and income are generally more accepting of individuals with mental illness. Corrigan et al., hypothesized that lower endorsement of stigmatizing attitudes towards women may be due to a lower rate of social dominance among women and/or higher rates of social empathy compared with men (48-50).

Stigma in people with substance use disorders lead to non-completion of treatment, poor recovery, and reintegration processes $(24,25)$. Literature also suggested that stigma lead to more difficulties in recovery, greater chances of relapse, and discontinuation of treatment (51, 52). The above findings conclude that stigma negatively influences the clinical parameters such as duration of the drinking and status of the illness among alcoholics. The present study did not report correlation between clinical variables and stigma among ADS patients. Literature on self stigma is more sparse in addiction and no study showed direct correlation of self stigma among ADS with clinical variables.

The correlation of socio-demographic and clinical variables between schizophrenia and ADS patients with selfstigma in our study reported no significant difference except for gender. This may be due to the fact that male participants outnumber females out of total sample size in this study. The logistic regression analysis showed that locality was found to be a predictor of stigma in schizophrenia, whereas locality and educational status were significant predictors of stigma in ADS in the present study. The results of regression analysis of previous studies demonstrated that current employment, gender, and level of education were not significant independent predictors of self-stigma in schizophrenia (32). Although the personal characteristics are of lesser importance to the formation of self-stigma, drinking related variables such as duration of drinking problem is found to be an independent predictor of stigma in ADS (53). Our scan of literature revealed no studies comparing schizophrenia and ADS patients in terms of having self-stigma. Therefore, further 
studies with large number of patients are needed to clarify whether differences occur between these disorders in terms of self-stigma.

\subsection{Conclusion}

In conclusion, self stigma is a significant problem in both ADS and schizophrenia patients. It is more severe in individuals living with ADS. Among schizophrenia and ADS subjects with self stigma, male patients were found to be more affected. Internalized stigma can have a negative impact on the well-being as well as psychiatric health and may impede the outcome of individuals suffering from the mental illnesses. Our study shows that locality and educational status are strong predictors of self stigma. Therefore, these factors need to be focused and investigated further to improve the overall quality of life and reduce the stigma.

\subsection{Limitations}

The sample size was small and the study was crosssectional. The longitudinal studies with larger sample size would be more reliable to infer causality from the findings. The other limitation is that the study was hospital based. Therefore, the studies in the community may provide more detail and reliable data.

\section{Footnotes}

Authors' Contributions: The authors of manuscript helped in edition and statistics; as well as funds.

\section{Conflict of Interests: None.}

\section{References}

1. Goffman E. Stigma: Notes on the Management of Spoiled Identity. Englewood Cliffs, NJ: Prentice-Hall; 1963.

2. Corrigan PW, Watson AC. Understanding the impact of stigma on people with mental illness. World Psychiatry. 2002;1(1):16-20. [PubMed: 16946807]. [PubMed Central: PMC1489832].

3. Ping Tsao CI, Tummala A, Roberts LW. Stigma in mental health care. Acad Psychiatry. 2008;32(2):70-2. doi:10.1176/appi.ap.32.2.70. [PubMed: 18349322].

4. Lau YW, Picco L, Pang S, Jeyagurunathan A, Satghare P, Chong SA, et al. Stigma resistance and its association with internalised stigma and psychosocial outcomes among psychiatric outpatients. Psychiatry Res. 2017;257:72-8. doi: 10.1016/j.psychres.2017.07.027. [PubMed: 28734239].

5. Switaj P, Grygiel P, Chrostek A, Nowak I, Wciorka J, Anczewska M. The relationship between internalized stigma and quality of life among people with mental illness: are self-esteem and sense of coherence sequential mediators? Qual Life Res. 2017;26(9):2471-8. doi: 10.1007/s11136-017-1596-3. [PubMed: 28530015]. [PubMed Central: PMC5548824].

6. Ritsher JB, Phelan JC. Internalized stigma predicts erosion of morale among psychiatric outpatients. Psychiatry Res. 2004;129(3):257-65. doi: 10.1016/j.psychres.2004.08.003. [PubMed: 15661319].
7. Yanos PT, Roe D, Markus K, Lysaker PH. Pathways between internalized stigma and outcomes related to recovery in schizophrenia spectrum disorders. Psychiatr Serv. 2008;59(12):1437-42. doi: 10.1176/appi.ps.59.12.1437. [PubMed: 19033171]. [PubMed Central: PMC2605316].

8. Rossi A, Galderisi S, Rocca P, Bertolino A, Rucci P, Gibertoni D, et al. Personal resources and depression in schizophrenia: The role of self-esteem, resilience and internalized stigma. Psychiatry Res. 2017;256:359-64. doi: 10.1016/j.psychres.2017.06.079. [PubMed: 28686933].

9. Margetic BA, Jakovljevic M, Ivanec D, Margetic B, Tosic G. Relations of internalized stigma with temperament and character in patients with schizophrenia. Compr Psychiatry. 2010;51(6):603-6. doi: 10.1016/j.comppsych.2010.02.010. [PubMed: 20965307].

10. Yanos PT, Lysaker PH, Roe D. Internalized stigma as a barrier to improvement in vocational functioning among people with schizophrenia-spectrum disorders. Psychiatry Res. 2010;178(1):211-3. doi: 10.1016/j.psychres.2010.01.003. [PubMed: 20417973]. [PubMed Central: PMC2914138].

11. Corrigan PW. The impact of stigma on severe mental illness. Cogn Behav Pract.1998;5(2):201-22. doi:10.1016/s1077-7229(98)80006-0.

12. Aukst Margetic B, Jakovljevic M, Margetic B. Socio-cognitivebehavioral structural equation model of internalized stigma in people with severe and persistent mental illness should include personality dimensions. Psychiatry Res. 2012;196(1):162-3. author reply 164. doi: 10.1016/j.psychres.2011.04.009. [PubMed: 21733580].

13. Mann CE, Himelein MJ. Factors associated with stigmatization of persons with mental illness. Psychiatr Serv. 2004;55(2):185-7. doi: 10.1176/appi.ps.55.2.185. [PubMed: 14762246].

14. Corrigan PW. Mental health stigma as social attribution: Implications for research methods and attitude change. Clinical Psychology: Science and Practice Clin Psycho Sci Pract. 2006;7(1):48-67. doi: 10.1093/clipsy.7.1.48.

15. Sarisoy G, Kacar OF, Pazvantoglu O, Korkmaz IZ, Ozturk A, Akkaya $\mathrm{D}$, et al. Internalized stigma and intimate relations in bipolar and schizophrenic patients: a comparative study. Compr Psychiatry. 2013;54(6):665-72. doi: 10.1016/j.comppsych.2013.02.002. [PubMed: 23601987].

16. Mueller B, Nordt C, Lauber C, Rueesch P, Meyer PC, Roessler W. Social support modifies perceived stigmatization in the first years of mental illness: a longitudinal approach. Soc Sci Med.2006;62(1):39-49. doi: 10.1016/j.socscimed.2005.05.014. [PubMed: 15992979].

17. Gerlinger G, Hauser M, De Hert M, Lacluyse K, Wampers M, Correll CU. Personal stigma in schizophrenia spectrum disorders: a systematic review of prevalence rates, correlates, impact and interventions. World Psychiatry. 2013;12(2):155-64. doi: 10.1002/wps.20040. [PubMed: 23737425]. [PubMed Central: PMC3683268].

18. Lien YJ, Chang HA, Kao YC, Tzeng NS, Lu CW, Loh CH. The impact of cognitive insight, self-stigma, and medication compliance on the quality of life in patients with schizophrenia. Eur Arch Psychiatry Clin Neurosci. 2018;268(1):27-38. doi: 10.1007/s00406-017-0829-3. [PubMed: 28756468].

19. World Health Organization . Global Status Report on Alcohol 2004. Geneva: World Health Organization; 2004.

20. Klingemann H, Gmel G. Alcohol and its social consequences: the forgotten dimension. Copenhagen: WHO Regional Office for Europe; 2001. doi: 10.1007/978-94-015-9725-8.

21. Room R. Stigma, social inequality and alcohol and drug use. Drug Alcohol Rev. 2005;24(2):143-55. doi:10.1080/09595230500102434. [PubMed: 16076584].

22. Angermeyer MC, Matschinger $H$. Social distance towards the mentally ill: results of representative surveys in the Federal Republic of Germany. Psychol Med. 1997;27(1):131-41. doi: 10.1017/S0033291796004205. [PubMed: 9122293]. 
23. Link BG, Phelan JC, Bresnahan M, Stueve A, Pescosolido BA. Public conceptions of mental illness: labels, causes, dangerousness, and social distance. Am J Public Health. 1999;89(9):1328-33. doi: 10.2105/AJPH.89.9.1328. [PubMed: 10474548]. [PubMed Central: PMC1508784].

24. Brener L, von Hippel W, von Hippel C, Resnick I, Treloar C. Perceptions of discriminatory treatment by staff as predictors of drug treatment completion: utility of a mixed methods approach. Drug Alcohol Rev. 2010;29(5):491-7. doi: 10.1111/j.1465-3362.2010.00173.x. [PubMed: 20887572].

25. Brewer KM. The Contextual Factors that Foster and Hinder the Process of Recovery for Alcohol Dependent Women. J Addict Nurs. 2006;17(3):175-80. doi: 10.1080/10884600600862194.

26. Larson JE, Corrigan P. The stigma of families with mental illness. Acad Psychiatry. 2008;32(2):87-91. doi: 10.1176/appi.ap.32.2.87. [PubMed: 18349326].

27. van der Sanden RL, Bos AE, Stutterheim SE, Pryor JB, Kok G. Experiences of stigma by association among family members of people with mental illness. Rehabil Psychol. 2013;58(1):73-80. doi: 10.1037/a0031752. [PubMed: 23438002].

28. Angermeyer MC, Matschinger H. Public beliefs about schizophrenia and depression: similarities and differences. Soc Psychiatry Psychiatr Epidemiol. 2003;38(9):526-34. doi: 10.1007/s00127-003-0676-6. [PubMed: 14504738].

29. Nolen-Hoeksema S, Hilt L. Possible contributors to the gender differences in alcohol use and problems. J Gen Psychol. 2006;133(4):357-74. doi: 10.3200/GENP.133.4.357-374. [PubMed: 17128956].

30. Ritsher JB, Otilingam PG, Grajales M. Internalized stigma of mental illness: psychometric properties of a new measure. Psychiatry Res. 2003;121(1):31-49. [PubMed:14572622].

31. Grover S, Singh A, Mattoo S. Validation of hindi version of internalized stigma of mental illness scale. Indian J Soc Psychiatry. 2016;32(2):104. doi: 10.4103/0971-9962.181089.

32. Brohan E, Elgie R, Sartorius N, Thornicroft G, G. AMIAN-Europe Study Group . Self-stigma, empowerment and perceived discrimination among people with schizophrenia in 14 European countries: the GAMIAN-Europe study. SchizophrRes. 2010;122(1-3):232-8. doi: 10.1016/j.schres.2010.02.1065. [PubMed: 20347271].

33. Link BG, Struening EL, Rahav M, Phelan JC, Nuttbrock L. On stigma and its consequences: evidence from a longitudinal study of men with dual diagnoses of mental illness and substance abuse. J Health Soc Behav. 1997;38(2):177-90. doi: 10.2307/2955424. [PubMed: 9212538].

34. Dinos S, Stevens S, Serfaty M, Weich S, King M. Stigma: the feelings and experiences of 46 people with mental illness. Qualitative study. $\mathrm{Br} \mathrm{J}$ Psychiatry. 2004;184:176-81. [PubMed: 14754832].

35. Schomerus G, Lucht M, Holzinger A, Matschinger H, Carta MG, Angermeyer MC. The stigma of alcohol dependence compared with other mental disorders: a review of population studies. Alcohol Alcohol. 2011;46(2):105-12. doi: 10.1093/alcalc/agq089. [PubMed: 21169612].

36. Rohit Garg BS, Chavan PA. Stigma and discrimination: how do persons with psychiatric disorders andsubstance dependence view themselves? India J Soc Psychiatry. 2012;28(3-4):121-30.

37. Girma E, Tesfaye M, Froeschl G, Moller-Leimkuhler AM, Dehning S, Muller N. Facility based cross-sectional study of self stigma among people with mental illness: towards patient empowerment approach. Int J Ment Health Syst. 2013;7(1):21. doi: 10.1186/1752-4458-7-21. [PubMed: 24004512]. [PubMed Central: PMC3848304].

38. Sibitz I, Unger A, Woppmann A, Zidek T, Amering M. Stigma resistance in patients with schizophrenia. Schizophr Bull. 2011;37(2):316-23. doi: 10.1093/schbul/sbp048. [PubMed: 19487336]. [PubMed Central: PMC3044638].
39. Lysaker PH, Roe D, Yanos PT. Toward understanding the insight paradox: internalized stigma moderates the association between insight and social functioning, hope, and self-esteem among people with schizophrenia spectrum disorders. Schizophr Bull. 2007;33(1):192-9. doi: 10.1093/schbul/sblo16. [PubMed: 16894025]. [PubMed Central: PMC2012366].

40. Lysaker PH, Davis LW, Warman DM, Strasburger A, Beattie N. Stigma social function and symptoms in schizophrenia and schizoaffective disorder: associations across 6 months. Psychiatry Res. 2007;149(13):89-95. doi:10.1016/j.psychres.2006.03.007. [PubMed: 17156853].

41. Yen CF, Chen CC, Lee Y, Tang TC, Yen JY, Ko CH. Self-stigma and its correlates among outpatients with depressive disorders. Psychiatr Serv. 2005;56(5):599-601. doi: 10.1176/appi.ps.56.5.599. [PubMed: 15872170].

42. Alonso J, Buron A, Bruffaerts R, He Y, Posada-Villa J, Lepine JP, et al. Association of perceived stigma and mood and anxiety disorders: results from the World Mental Health Surveys. Acta Psychiatr Scand. 2008;118(4):305-14. doi: 10.1111/j.1600-0447.2008.01241.x. [PubMed: 18754833]. [PubMed Central: PMC3040096].

43. Jadhav S, Littlewood R, Ryder AG, Chakraborty A, Jain S, Barua M. Stigmatization of severe mental illness in India: Against the simple industrialization hypothesis. Indian J Psychiatry. 2007;49(3):18994. doi: 10.4103/0019-5545.37320. [PubMed: 20661385]. [PubMed Central: PMC2902092]

44. Loganathan S, Murthy SR. Experiences of stigma and discrimination endured by people suffering from schizophrenia. Indian J Psychiatry. 2008;50(1):39-46. doi: 10.4103/0019-5545.39758. [PubMed: 19771306]. [PubMed Central: PMC2745872].

45. Ho WW, Chiu MY, Lo WT, Yiu MG. Recovery components as determinants of the health-related quality of life among patients with schizophrenia: structural equation modelling analysis. Aust N Z J Psychiatry. 2010;44(1):71-84. doi: 10.3109/00048670903393654. [PubMed: 20073569].

46. Corrigan PW, Powell KJ, Rusch N. How does stigma affect work in people with serious mental illnesses? Psychiatr Rehabil J. 2012;35(5):381-4. doi: 10.1037/ho094497. [PubMed: 23116379].

47. Keyes KM, Hatzenbuehler ML, McLaughlin KA, Link B, Olfson M, Grant $\mathrm{BF}$, et al. Stigma and treatment for alcohol disorders in the United States. Am J Epidemiol. 2010;172(12):1364-72. doi: 10.1093/aje/kwq304. [PubMed: 21044992]. [PubMed Central: PMC2998202].

48. Farina A. Are women nicer people than men? Sex and the stigma of mental disorders. Clinical Psychology Review. 1981;1(2):223-43. doi: 10.1016/0272-7358(81)90005-2.

49. Corrigan PW, Watson AC. The stigma of psychiatric disorders and the gender, ethnicity, and education of the perceiver. Community Ment Health J. 2007;43(5):439-58. doi: 10.1007/s10597-007-9084-9. [PubMed: 17876705].

50. Stigma FA. Mueser KT, Tarrier N, editors. Handbook of Social Functioning in Schizophrenia. Needham Heights, MA: Allyn \& Bacon, Inc; 1998. p. $247-79$.

51. Luoma JB, Twohig MP, Waltz T, Hayes SC, Roget N, Padilla M, et al. An investigation of stigma in individuals receiving treatment for substance abuse. Addict Behav. 2007;32(7):1331-46. doi: 10.1016/j.addbeh.2006.09.008. [PubMed: 17092656].

52. Sirey JA, Bruce ML, Alexopoulos GS, Perlick DA, Raue P, Friedman SJ, et al. Perceived stigma as a predictor of treatment discontinuation in young and older outpatients with depression. Am J Psychiatry. 2001;158(3):479-81. doi:10.1176/appi.ajp.158.3.479. [PubMed: 11229992]

53. Schomerus G, Corrigan PW, Klauer T, Kuwert P, Freyberger HJ, Lucht M. Self-stigma in alcohol dependence: consequences for drinking-refusal self-efficacy. Drug Alcohol Depend. 2011;114(1):12-7. doi: 10.1016/j.drugalcdep.2010.08.013. [PubMed: 20933344]. 
Table 2. Distribution of Self-Stigma in Schizophrenia Patients $(N=50)^{a}$

\begin{tabular}{|c|c|c|c|c|c|c|c|c|}
\hline Variables & Alienation & $\begin{array}{c}\text { Stereotype } \\
\text { Endorsement }\end{array}$ & $\begin{array}{l}\text { Discrimination } \\
\text { Experience }\end{array}$ & $\begin{array}{c}\text { Social } \\
\text { Withdrawal }\end{array}$ & $\begin{array}{c}\text { Stigma } \\
\text { Resistance scores }\end{array}$ & Total & $\chi^{2}$ & Pvalue $^{b}$ \\
\hline \multicolumn{9}{|l|}{ Age, $y$} \\
\hline $\begin{array}{l}\text { Less than } \\
30\end{array}$ & & & & & & & 4.03 & $0.40, \mathrm{NS}$ \\
\hline Absent & $7(43.75)$ & $8(50.00)$ & $7(43.75)$ & $8(50.00)$ & $9(56.25)$ & $7(43.75)$ & & \\
\hline Present & $9(56.25)$ & $8(50.00)$ & $9(56.25)$ & $8(50.00)$ & $7(43.75)$ & $9(56.25)$ & & \\
\hline $30-45$ & & & & & & & 0.76 & 0.94, NS \\
\hline Absent & $14(53.84)$ & $13(50.00)$ & $13(50.00)$ & $14(53.84)$ & $14(53.84)$ & $14(53.84)$ & & \\
\hline Present & $12(46.15)$ & $13(50.00)$ & $13(50.00)$ & $12(46.15)$ & $12(46.15)$ & $12(46.15)$ & & \\
\hline $\begin{array}{l}\text { More than } \\
45\end{array}$ & & & & & & & 5.42 & 0.24 , NS \\
\hline Absent & $4(50.00)$ & $5(62.50)$ & $4(50.00)$ & $4(50.00)$ & $4(50.00)$ & $4(50.00)$ & & \\
\hline Present & $4(50.00)$ & $3(37.50)$ & $4(50.00)$ & $4(50.00)$ & $4(50.00)$ & $4(50.00)$ & & \\
\hline \multicolumn{9}{|l|}{ Sex } \\
\hline Male & & & & & & & 1.31 & 0.25 , NS \\
\hline Absent & $10(41.66)$ & $9(37.50)$ & $10(41.66)$ & $10(41.66)$ & $11(45.83)$ & $10(41.66)$ & & \\
\hline Present & $14(58.33)$ & $15(62.50)$ & $14(58.33)$ & $14(58.33)$ & $13(54.16)$ & $14(58.33)$ & & \\
\hline Female & & & & & & & 3.03 & 0.55 , NS \\
\hline Absent & $15(57.69)$ & $17(65.38)$ & $14(53.84)$ & $16(61.53)$ & $16(61.53)$ & $15(57.69)$ & & \\
\hline Present & $11(42.30)$ & $9(34.61)$ & $12(46.15)$ & $10(38.46)$ & $10(38.46)$ & $11(42.30)$ & & \\
\hline \multicolumn{9}{|l|}{ Marital status } \\
\hline Married & & & & & & & 1.33 & 0.85 , NS \\
\hline Absent & $16(57.14)$ & $15(53.57)$ & $14(50.00)$ & $16(57.14)$ & $15(53.57)$ & $15(53.57)$ & & \\
\hline Present & $12(42.85)$ & $13(46.42)$ & $14(50.00)$ & $12(42.85)$ & $13(46.42)$ & $13(46.42)$ & & \\
\hline Unmarried & & & & & & & 9.75 & $0.044, S$ \\
\hline Absent & $7(58.33)$ & $7(58.33)$ & $7(58.33)$ & $7(58.33)$ & $9(75.00)$ & $7(58.33)$ & & \\
\hline Present & $5(41.66)$ & $5(41.66)$ & $5(41.66)$ & $5(41.66)$ & $3(25.00)$ & $5(41.66)$ & & \\
\hline Divorced & & & & & & & 9.52 & $0.049, S$ \\
\hline Absent & $2(20.00)$ & $4(40.00)$ & $3(30.00)$ & $3(30.00)$ & $3(30.00)$ & $3(30.00)$ & & \\
\hline Present & $8(80.00)$ & $6(60.00)$ & $7(70.00)$ & $7(70.00)$ & $7(70.00)$ & $7(70.00)$ & & \\
\hline Widow & 0 & 0 & 0 & 0 & 0 & 0 & - & \\
\hline Others & 0 & 0 & 0 & 0 & 0 & 0 & - & \\
\hline \multicolumn{9}{|l|}{ Education status } \\
\hline $1^{\mathrm{st}}-5^{\mathrm{th}}$ std & & & & & & & 1.73 & $0.78, \mathrm{NS}$ \\
\hline Absent & $9(42.85)$ & $10(47.61)$ & $9(42.85)$ & $9(42.85)$ & $10(47.61)$ & $9(42.85)$ & & \\
\hline Present & $12(57.14)$ & $11(52.38)$ & $12(57.14)$ & $12(57.14)$ & $11(52.38)$ & $12(57.14)$ & & \\
\hline $6^{\text {th }}-10^{\text {th }}$ std & & & & & & & 5.33 & 0.25 , NS \\
\hline Absent & $12(63.15)$ & $14(73.68)$ & $10(52.63)$ & $14(73.68)$ & $12(63.15)$ & $12(63.15)$ & & \\
\hline Present & $7(36.84)$ & $5(26.31)$ & $9(47.36)$ & $5(26.31)$ & $7(36.84)$ & $7(36.84)$ & & \\
\hline $11^{\text {th }}-12^{\text {th }}$ std & & & & & & & 0.00 & $1.00, \mathrm{NS}$ \\
\hline Absent & $3(50.00)$ & $3(50.00)$ & $3(50.00)$ & $3(50.00)$ & $3(50.00)$ & $3(50.00)$ & & \\
\hline
\end{tabular}




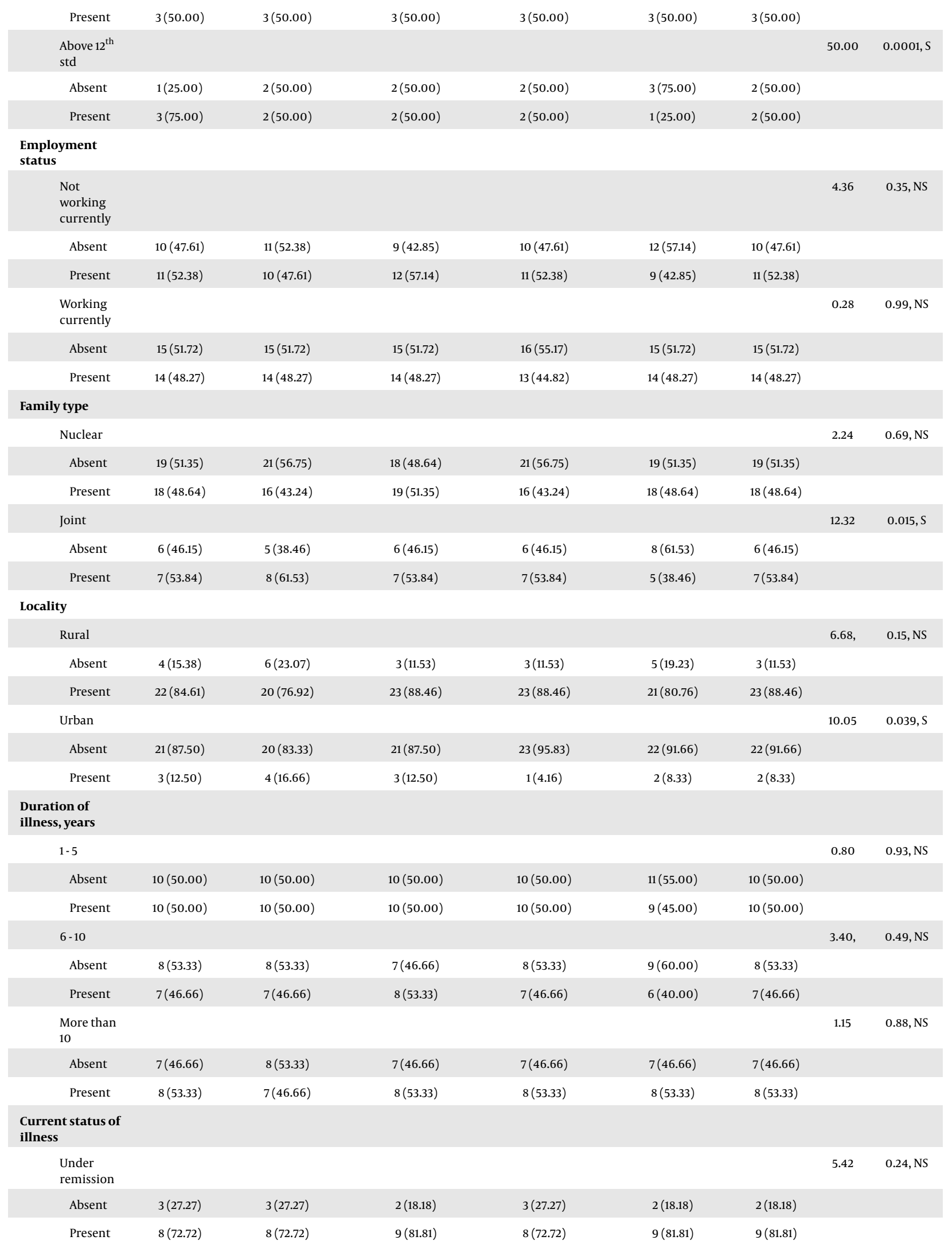




\begin{tabular}{|c|c|c|c|c|c|c|c|c|}
\hline $\begin{array}{l}\text { Not under } \\
\text { remission }\end{array}$ & & & & & & & 1.76 & $0.77, \mathrm{NS}$ \\
\hline Absent & $22(56.41)$ & $23(58.97)$ & $22(56.41)$ & $23(58.97)$ & $25(64.10)$ & $23(58.97)$ & & \\
\hline
\end{tabular}

${ }^{\mathrm{a}}$ Values are expressed as No. (\%).

${ }^{\mathrm{b}} \mathrm{NS}$, non significant and S, significant with P value $<0.05$ 
Table 3. Distribution of Self-Stigma in ADS Patients $(N=50)^{\mathrm{a}}$

\begin{tabular}{|c|c|c|c|c|c|c|c|c|}
\hline Variables & Alienation & $\begin{array}{c}\text { Stereotype } \\
\text { Endorsement }\end{array}$ & $\begin{array}{l}\text { Discrimination } \\
\text { Experience }\end{array}$ & $\begin{array}{c}\text { Social } \\
\text { Withdrawal }\end{array}$ & $\begin{array}{c}\text { Stigma } \\
\text { Resistance Scores }\end{array}$ & Total & $\chi^{2}$ & Pvalue $^{b}$ \\
\hline \multicolumn{9}{|l|}{ Age, y } \\
\hline Less than 30 & & & & & & & 6.52 & 0.16 , NS \\
\hline Absent & $3(42.85)$ & $2(28.57)$ & $3(42.85)$ & $3(42.85)$ & $3(42.85)$ & $1(14.28)$ & & \\
\hline Present & $4(57.14)$ & $5(71.42)$ & $4(57.14)$ & $4(57.14)$ & $4(57.14)$ & $6(85.71)$ & & \\
\hline $30-45$ & & & & & & & 0.78 & 0.94, NS \\
\hline Absent & $12(36.36)$ & $11(33.33)$ & $12(36.36)$ & $13(39.39)$ & $12(36.36)$ & $12(36.36)$ & & \\
\hline Present & $21(63.63)$ & $22(66.66)$ & $21(63.63)$ & $20(60.60)$ & $21(63.63)$ & $21(63.63)$ & & \\
\hline $\begin{array}{l}\text { More than } \\
45\end{array}$ & & & & & & & 0.00 & $1.00, \mathrm{NS}$ \\
\hline Absent & $4(40.00)$ & $4(40.00)$ & $4(40.00)$ & $4(40.00)$ & $4(40.00)$ & $4(40.00)$ & & \\
\hline Present & $6(60.00)$ & $6(60.00)$ & $6(60.00)$ & $6(60.00)$ & $6(60.00)$ & $6(60.00)$ & & \\
\hline \multicolumn{9}{|l|}{ Sex } \\
\hline Male & & & & & & & 0.81 & 0.93 , NS \\
\hline Absent & $19(38.00)$ & $17(34.00)$ & $19(38.00)$ & $20(40.00)$ & $19(38.00)$ & $17(34.00)$ & & \\
\hline Present & $31(62.00)$ & $33(66.00)$ & $31(62.00)$ & $30(60.00)$ & $31(62.00)$ & $33(66.00)$ & & \\
\hline Female & 0 & 0 & 0 & 0 & 0 & 0 & & \\
\hline Absent & 0 & 0 & 0 & 0 & 0 & 0 & & \\
\hline Present & & & & & & & & \\
\hline \multicolumn{9}{|l|}{ Marital status } \\
\hline Married & & & & & & & 1.61 & $0.80, \mathrm{NS}$ \\
\hline Absent & $12(42.85)$ & $10(35.61)$ & $12(42.85)$ & $12(42.85)$ & $12(42.85)$ & $11(39.28)$ & & \\
\hline Present & $16(57.14)$ & $18(64.28)$ & $16(57.14)$ & $16(57.14)$ & $16(57.14)$ & $17(60.71)$ & & \\
\hline Unmarried & & & & & & & 0.00 & 1.00, NS \\
\hline Absent & $5(33.33)$ & $5(33.33)$ & $5(33.33)$ & $5(33.33)$ & $5(33.33)$ & $4(26.66)$ & & \\
\hline Present & $10(66.66)$ & $10(66.66)$ & $10(66.66)$ & $10(66.66)$ & $10(66.66)$ & $11(73.33)$ & & \\
\hline Divorced & & & & & & & 0.00 & 1.00, NS \\
\hline Absent & $2(28.57)$ & $2(28.57)$ & $2(28.57)$ & $2(28.57)$ & $2(28.57)$ & $2(28.57)$ & & \\
\hline Present & $5(71.42)$ & $5(71.42)$ & $5(71.42)$ & $5(71.42)$ & $5(71.42)$ & $5(71.42)$ & & \\
\hline Widow & 0 & 0 & 0 & 0 & 0 & 0 & - & \\
\hline Others & 0 & 0 & 0 & 0 & 0 & 0 & - & \\
\hline \multicolumn{9}{|l|}{ Education status } \\
\hline $1^{\mathrm{st}}-5^{\mathrm{th}} \mathrm{std}$ & & & & & & & 0.00 & 1.00, NS \\
\hline Absent & $5(26.31)$ & $5(26.31)$ & $5(26.31)$ & $5(26.31)$ & $5(26.31)$ & $4(21.05)$ & & \\
\hline Present & $14(73.68)$ & $14(73.68)$ & $14(73.68)$ & $14(73.68)$ & $14(73.68)$ & $15(78.94)$ & & \\
\hline $6^{\text {th }}-10^{\text {th }}$ std & & & & & & & 1.79 & 0.44, NS \\
\hline Absent & $5(33.33)$ & $6(40)$ & $5(33.33)$ & $7(46.66)$ & $6(40)$ & $7(46.66)$ & & \\
\hline Present & $10(66.66)$ & $9(60)$ & $10(66.66)$ & $8(53.33)$ & $9(60)$ & $8(53.33)$ & & \\
\hline $11^{\text {th }}-12^{\text {th }}$ std & & & & & & & 4.61 & $0.32, \mathrm{NS}$ \\
\hline Absent & $4(50.00)$ & $3(37.50)$ & $4(50.00)$ & $4(50.00)$ & $4(50.00)$ & $3(37.50)$ & & \\
\hline
\end{tabular}




\begin{tabular}{|c|c|c|c|c|c|c|c|c|}
\hline Present & $4(50.00)$ & $5(62.50)$ & $4(50.00)$ & $4(50.00)$ & $4(50.00)$ & $5(62.50)$ & & \\
\hline $\begin{array}{l}\text { Above } 12^{\text {th }} \\
\text { std }\end{array}$ & & & & & & & 10.37 & $0.034, S$ \\
\hline Absent & $7(87.50)$ & $6(75.00)$ & $7(87.50)$ & $7(87.50)$ & $7(87.50)$ & $7(87.50)$ & & \\
\hline Present & $1(12.50)$ & $2(25.00)$ & $1(12.50)$ & $1(12.50)$ & $1(12.50)$ & $1(12.50)$ & & \\
\hline \multicolumn{9}{|l|}{$\begin{array}{l}\text { Employment } \\
\text { status }\end{array}$} \\
\hline $\begin{array}{l}\text { Not } \\
\text { working } \\
\text { currently }\end{array}$ & & & & & & & 1.79 & 0.77 , NS \\
\hline Absent & $8(34.78)$ & $7(30.43)$ & $8(34.78)$ & $9(39.13)$ & $8(34.78)$ & $7(30.43)$ & & \\
\hline Present & $15(65.21)$ & $16(69.56)$ & $15(65.21)$ & $14(60.86)$ & $15(65.21)$ & $16(69.56)$ & & \\
\hline $\begin{array}{l}\text { Working } \\
\text { currently }\end{array}$ & & & & & & & 0.80 & 0.93, NS \\
\hline Absent & $11(40.74)$ & $10(37.03)$ & $10(37.03)$ & $11(40.74)$ & $11(40.74)$ & $10(37.03)$ & & \\
\hline Present & $16(59.25)$ & $17(62.96)$ & $17(62.96)$ & $16(59.25)$ & $16(59.25)$ & $17(62.96)$ & & \\
\hline \multicolumn{9}{|l|}{ Family type } \\
\hline Nuclear & & & & & & & 1.91 & 0.75 , NS \\
\hline Absent & $15(44.11)$ & $13(38.23)$ & $14(41.17)$ & $16(47.05)$ & $15(44.11)$ & $13(38.23)$ & & \\
\hline Present & $19(55.88)$ & $21(61.16)$ & $20(58.82)$ & $18(52.94)$ & $19(55.88)$ & $21(67.16)$ & & \\
\hline Joint & & & & & & & 1.49 & 0.82, NS \\
\hline Absent & $4(25.00)$ & $4(25.00)$ & $5(31.25)$ & $4(25.00)$ & $4(25.00)$ & $4(25.00)$ & & \\
\hline Present & $12(75.00)$ & $12(75.00)$ & $11(68.75)$ & $12(75.00)$ & $12(75.00)$ & $12(75.00)$ & & \\
\hline \multicolumn{9}{|l|}{ Locality } \\
\hline Rural & & & & & & & 1.73 & 0.78, NS \\
\hline Absent & $6(17.14)$ & $5(14.28)$ & $7(20.00)$ & $7(20.00)$ & $6(17.14)$ & $5(14.28)$ & & \\
\hline Present & $29(82.85)$ & $30(85.71)$ & $28(80.00)$ & $28(80.00)$ & $29(82.85)$ & $30(85.71)$ & & \\
\hline Urban & & & & & & & 4.42 & 0.35, NS \\
\hline Absent & $13(86.66)$ & $12(80.00)$ & $12(80.00)$ & $13(86.66)$ & $13(86.66)$ & $12(80.00)$ & & \\
\hline Present & $2(13.33)$ & $3(20.00)$ & $3(20.00)$ & $2(13.33)$ & $2(13.33)$ & $3(20.00)$ & & \\
\hline \multicolumn{9}{|l|}{$\begin{array}{l}\text { Duration of } \\
\text { illness, years }\end{array}$} \\
\hline $1-5$ & & & & & & & 0.99 & 0.91 , NS \\
\hline Absent & $6(27.27)$ & $6(27.27)$ & $7(31.81)$ & $6(27.27)$ & $6(27.27)$ & $5(22.72)$ & & \\
\hline Present & $16(72.72)$ & $16(72.72)$ & $15(68.18)$ & $16(72.72)$ & $16(72.72)$ & $17(77.27)$ & & \\
\hline $6-10$ & & & & & & & 4.86 & 0.30, NS \\
\hline Absent & $7(41.17)$ & $5(29.41)$ & $7(41.17)$ & $7(41.17)$ & $7(41.17)$ & $6(35.29)$ & & \\
\hline Present & $10(58.82)$ & $12(70.58)$ & $10(58.82)$ & $10(58.82)$ & $10(58.82)$ & $11(64.70)$ & & \\
\hline $\begin{array}{l}\text { More than } \\
10\end{array}$ & & & & & & & 7.29 & 0.12 , NS \\
\hline Absent & $6(54.54)$ & $6(54.54)$ & $5(45.45)$ & $7(63.63)$ & $6(54.54)$ & $6(54.54)$ & & \\
\hline Present & $5(45.45)$ & $5(45.45)$ & $6(54.54)$ & $4(36.36)$ & $5(45.45)$ & $5(45.45)$ & & \\
\hline \multicolumn{9}{|l|}{$\begin{array}{l}\text { Current status of } \\
\text { illness }\end{array}$} \\
\hline $\begin{array}{l}\text { Under } \\
\text { remission }\end{array}$ & & & & & & & 0.00 & 1.00, NS \\
\hline Absent & $2(12.5)$ & $2(12.5)$ & $2(12.5)$ & $2(12.5)$ & $2(12.5)$ & $2(12.5)$ & & \\
\hline Present & $14(87.50)$ & $14(87.50)$ & $14(87.50)$ & $14(87.50)$ & $14(87.50)$ & $14(87.50)$ & & \\
\hline
\end{tabular}




\begin{tabular}{cccccc}
\hline $\begin{array}{l}\text { Not under } \\
\text { remission }\end{array}$ & & & & & \\
& & & & \\
Absent & $19(55.88)$ & $19(55.88)$ & $19(55.88)$ & $19(55.88)$ & $19(55.88)$ \\
\hline Present & $15(44.11)$ & $15(44.11)$ & $15(44.11)$ & $15(44.11)$ & $15(55.88)$ \\
\hline
\end{tabular}

${ }^{\mathrm{a}}$ Values are expressed as No. (\%)

${ }^{\mathrm{b}} \mathrm{NS}$, non significant and S, significant with P value $<0.05$. 